\title{
Codium fragile subsp. fragile (Suringar) Hariot in Tunisia: morphological data and status of knowledge
}

\author{
Wafa Cherif $^{1,2,3}$, Leila Ktari ${ }^{1, *}$, Monia El Bour ${ }^{1}$, Abdellatif Boudabous ${ }^{3}$ and Micheline \\ Grignon-Dubois ${ }^{2}$
}

${ }^{1}$ National Institute of Marine Sciences and Technologies, 28, Rue 2 mars 1934, Salammbô 2025, Tunisia

${ }^{2}$ Univ. Bordeaux, EPOC, UMR 5805, F-33400 Talence, France

${ }^{3}$ Faculty of Mathematical, Physical and Natural Sciences of Tunis, Tunis 2092, Tunisia

The Mediterranean Sea is currently facing dramatic changes and threats, including change in native species and accidental introductions. The introduced green alga Codium fragile subsp. fragile (Suringar) Hariot influences diversity and community structure in some parts of the world. This paper documents the distribution of this species in Tunisia and provides a morphological description of $C$. fragile subsp. fragile in Northern Tunisia. Results confirm the identity of Tunisian specimens as the invasive subspecies $C$. fragile subsp. fragile. This is the first morphological characterization of this subspecies in Tunisia.

Key Words: Codium fragile subsp. fragile; invasive species; morphological description; Northern Tunisia

\section{INTRODUCTION}

Human activities such as aquaculture, fishing and interoceanic shipping have helped favoring species dispersal and increasing the risk of introduction into coastal marine ecosystems. Introduced species are often free from predators, competitors or pathogens in the areas of invasion allowing them to become common and successful in the new area, to displace indigenous species and to become economic pests (Trowbridge 1995). The ecological impacts of invasive marine species represent a major problem to global biodiversity; non-native species can alter profoundly the host ecosystems.

Codium Stackhouse (Codiaceae, Bryopsidales, Chlorophyta) is a cosmopolitan genus widely distributed in marine environments throughout the world, with the exception of the Polar Regions. It currently comprises about
143 specific and infra-specific taxa currently accepted taxonomically according to Guiry and Guiry (2016) that are mainly found in temperate and subtropical zones (Verbruggen et al. 2007). Five species are present in Tunisia, namely Codium bursa (L.) C. Agardh, Codium decorticatum (Woodward) Howe, Codium effusum (Rafinesque) Delle Chiaje, Codium fragile (Suringar) Hariot, and Codium vermilara (Olivi) Delle Chiaje (Gallardo et al. 1993). Among them only C. fragile is an introduced one. All over the world, there are ten subspecies of $C$. fragile (Guiry and Guiry 2016), of which three are considered invasive (Provan et al. 2008). From these, only the subsp. fragile (Syn. C. fragile subsp. tomentosoides, C. fragile subsp. scandinavicum) has received more attention over the years because of its successful invasion in both Northern and
(9) $\$$ This is an Open Access article distributed under the terms of the Creative Commons Attribution Non-Commercial License (http://creativecommons.org/licenses/by-nc/3.0/) which permits unrestricted non-commercial use, distribution, and reproduction in any medium, provided the original work is properly cited.
Received January 20, 2016, Accepted April 17, 2016

* Corresponding Author

E-mail: leila.ktari@instm.rnrt.tn Tel: +216-71-276121 
Southern hemispheres (Silva 1955, Trowbridge and Todd 2001, Hubbard and Garbary 2002). C. fragile subsp. fragile has become a nuisance by achieving high biomass and outcompeting resident species on various spatial scales. This subspecies has spread rapidly in temperate areas throughout the globe from its native range in Japan (Silva 1955, Trowbridge and Todd 2001). Its various strategies of reproduction: sexual, asexual, and vegetative (Mathieson et al. 2003), and its capacity for long-distance dispersal (Watanabe et al. 2009) contribute to the invasive success of the species, leading to ecological and economic concerns. Importation of Asian shellfish (oysters and mussels) appears as a major vector of introduction, respectively $44 \%$ in Europe and $46 \%$ in the Mediterranean Sea (Zenetos et al. 2012).

Considered as native to Japan, C. fragile subsp. fragile is a North-Pacific taxon that has been introduced worldwide (Burrows 1991, Provan et al. 2008). It first appeared on the shores of Holland before 1900 and later spread throughout Europe, rapidly colonizing the Mediterranean Sea (Silva 1955). The first introduction into the Mediterranean Sea probably dates from World War II and presumably was due to military shipping (Verlaque 1994). C. fragile was reported for the first time in Tunisia, in Northern Tunisia (lagoon of Bizerte) as C. fragile without mention of the subspecies (Djellouli 1987). The alga was later identified as C. fragile subsp. fragile (Sghaier et al. 2016).

The distribution and morphology of Codium fragile has been well described all over the world. In the Mediterranean Sea, C. fragile has been always considered as the subspecies tomentosoides (Gallardo et al. 1993). However, the recent signalization of the subspecies atlanticum on the Italian coasts (Petrocelli et al. 2013) must lead, from now on, to bring more attention to the criteria used when describing $C$. fragile. In this context, this paper describes the distribution and morphology of $C$. fragile Tunisian specimens with emphasis on the subspecies anatomical and morphological characteristics such as size and shape of thalli and utricles.

\section{MATERIALS AND METHODS}

\section{Sampling sites}

Samples were collected from April 2010 to July 2015 at two different sites located in the north of Tunisia: Marsa (Bay of Tunis) and Bizerte lagoon. Collection data are reported in Table 1.

Marsa is a rocky sandy area, rich with algae wildlife, open to the Mediterranean Western basin and located near areas with heavy boat traffic such as Goulette and Sidi Bou Said ports. The Lagoon of Bizerte has a surface area of $150 \mathrm{~km}^{2}$ with a mean depth of $7 \mathrm{~m}$. This lagoon is subject to strong human pressures such as urban, industrial, and agricultural pollutions as well as the breeding of mussels and oysters in Menzel Jemil.

\section{Sampling method and identification}

All specimens were collected by hand in shallow water $(<2 \mathrm{~m})$. Collected samples were transported freshly in an icebox. In the laboratory, the algal material was cleaned with seawater to remove the maximum of epiphytes, and then was kept in $2 \%$ formaldehyde-seawater. Fixed materials were identified using a binocular microscope (Alphaphot-2.YS2-H; Nikon, Tokyo, Japan). The identification was based on different taxonomical keys. To determinate the subspecies of Codium fragile, the morpho-anatomical details were analyzed following the keys reported in the literature (Silva 1955, Trowbridge 1998, Hubbard and Garbary 2002). Eleven morphometric traits (3 macroscopic and 8 microscopic) were measured on thalli (n $=5$ ). Utricles were sampled at approximately $2 \mathrm{~cm}$ from the tip of the plant and 5 utricles were measured for each plant.

\section{RESULTS AND DISCUSSION}

\section{Morphology of Codium fragile subsp. fragile}

The green alga $C$. fragile subsp. fragile has spongy irregularly dichotomous branched thallus (Fig. 1A). Internal structure is composed of intertwined colorless medullary filaments amorphously cylindrical (Fig. 1C) and a green palisade-like layer of vesicles called utricles (Fig. 1D) prolonging into a long pointed mucron (Fig. 1E). The

Table 1. Collection data of Codium fragile subsp. fragile

\begin{tabular}{cll}
\hline $\begin{array}{c}\text { Sampling } \\
\text { sites }\end{array}$ & \multicolumn{1}{c}{ Geographic coordinates } & $\begin{array}{c}\text { Sampling } \\
\text { dates }\end{array}$ \\
\hline Marsa & $36^{\circ} 53^{\prime} 03.97^{\prime \prime} \mathrm{N}, 10^{\circ} 20^{\prime} 14.22^{\prime \prime} \mathrm{E}$ & Apr 27, 2010 \\
& $36^{\circ} 52^{\prime} 56.99^{\prime \prime} \mathrm{N}, 10^{\circ} 20^{\prime} 27.02^{\prime \prime} \mathrm{E}$ & May 27, 2011 \\
& $36^{\circ} 52^{\prime} 56.99^{\prime \prime} \mathrm{N}, 10^{\circ} 20^{\prime} 27.02^{\prime \prime} \mathrm{E}$ & Aug 20, 2015 \\
Lagoon of & $37^{\circ} 13^{\prime} 31.19^{\prime \prime} \mathrm{N}, 9^{\circ} 55^{\prime} 39.43^{\prime \prime} \mathrm{E}$ & Jun 30, 2011 \\
Bizerte & $37^{\circ} 13^{\prime} 24.07^{\prime \prime} \mathrm{N}, 9^{\circ} 55^{\prime} 53.00^{\prime \prime} \mathrm{E}$ & Jul 19, 2011 \\
& $37^{\circ} 13^{\prime} 24.07^{\prime \prime} \mathrm{N}, 9^{\circ} 55^{\prime} 53.00^{\prime \prime} \mathrm{E}$ & Feb 20, 2014 \\
& $37^{\circ} 13^{\prime} 50.26^{\prime \prime} \mathrm{N}, 9^{\circ} 51^{\prime} 17.61^{\prime \prime} \mathrm{E}$ & Jun 1, 2015 \\
& $37^{\circ} 13^{\prime} 46.12^{\prime \prime} \mathrm{N}, 9^{\circ} 51^{\prime} 15.90^{\prime \prime} \mathrm{E}$ & Sep 9, 2015 \\
\hline
\end{tabular}



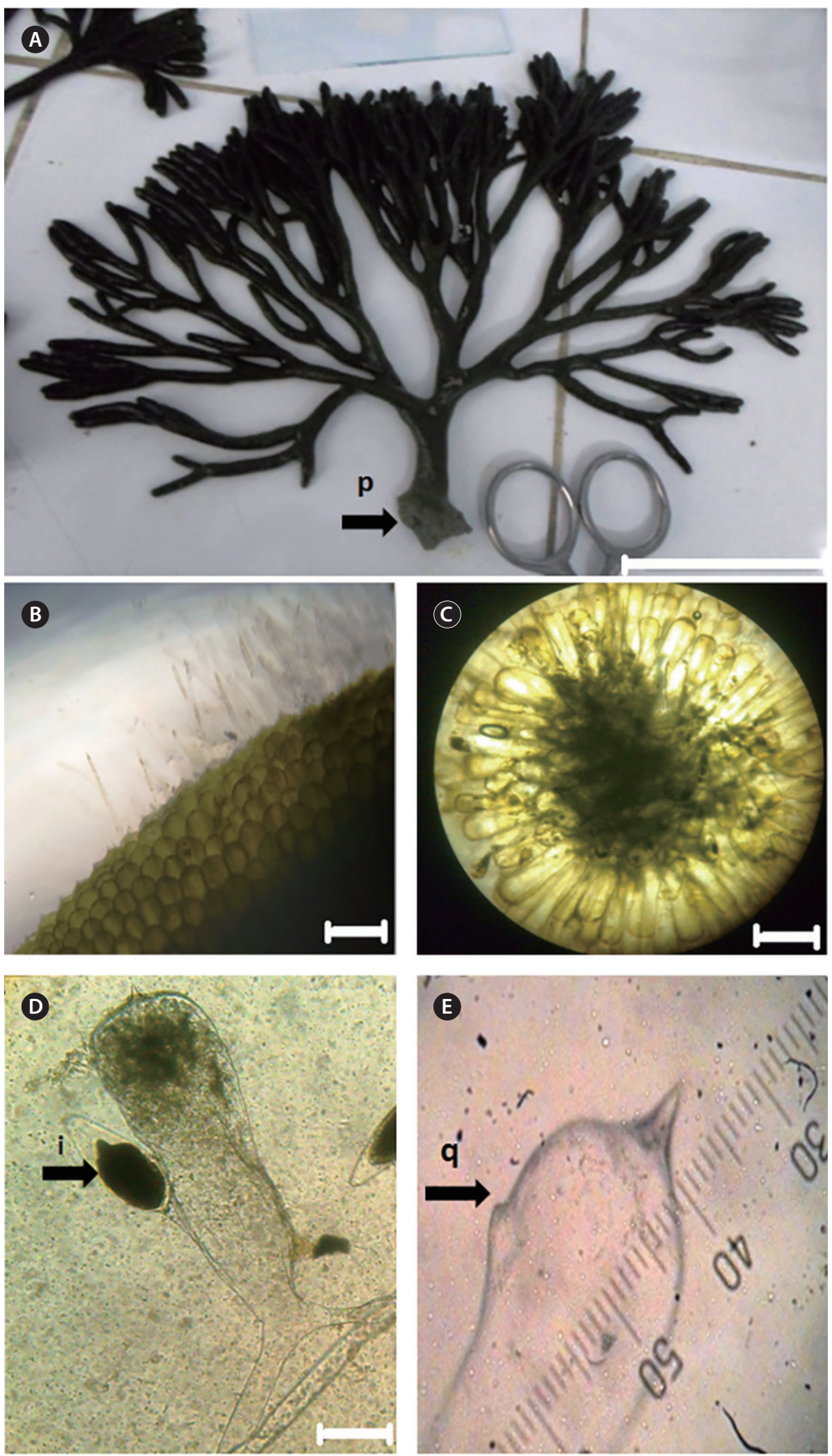

Fig. 1. Photographs of Tunisian specimens of Codium fragile subsp. fragile. (A) Dichtomous thallus (p, spongy base). (B) Wall of thallus showing hairs. (C) Utricles in cross section of thallus. (D) Utricle. i, gametangium. (E) Close view of long and pointed mucron on top of utricle. $q$, hairs scar. Scale bars represent: $A, 10 \mathrm{~cm}$; B \&, $1 \mathrm{~cm} ; \mathrm{D}, 100 \mu \mathrm{m}$. 


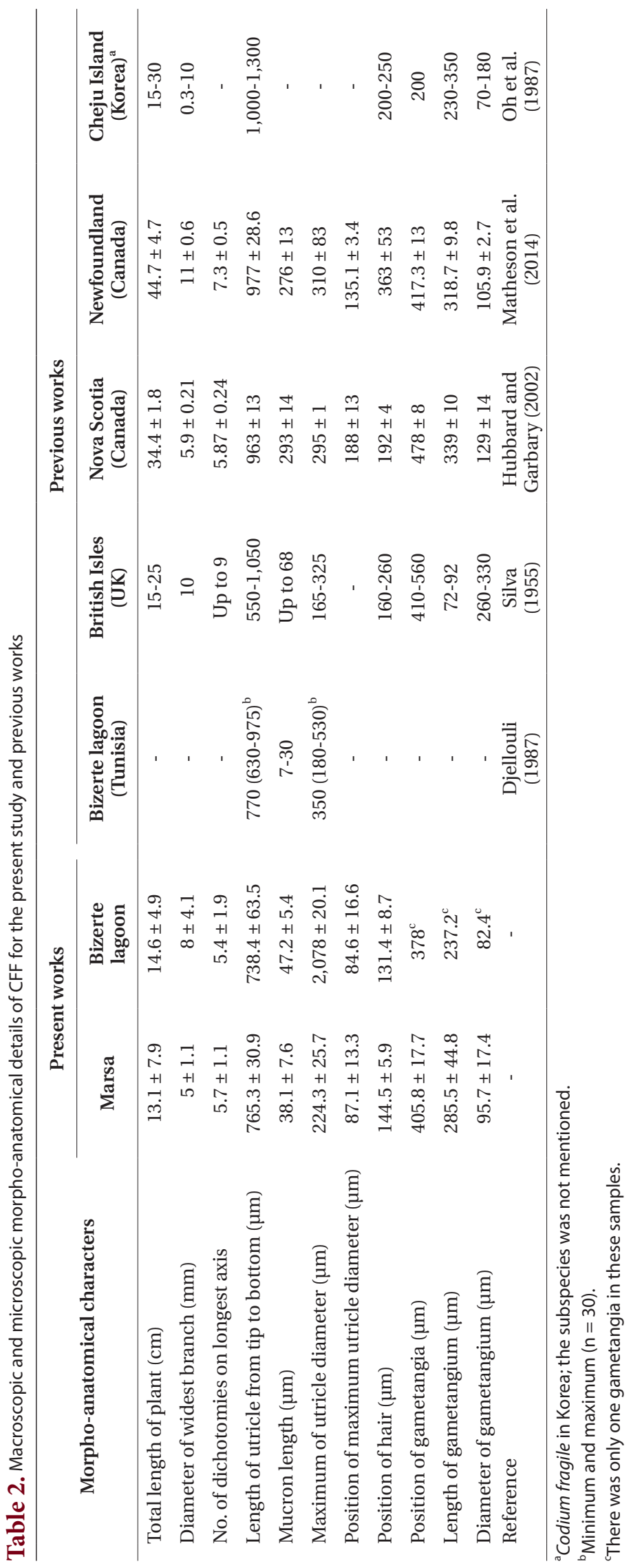


presence of pointed mucron, characteristic of C. fragile, confirmed the identification of the species.

Macroscopic and microscopic morphometric data of C. fragile subsp. fragile collected from Northern Tunisian coast were compared to data reported in the literature for C. fragile subsp. fragile specimens collected from Europe, Canada, and Korea (Table 2).

Macroscopically, our specimens were found similar to the diagnostic characters of plants collected in Bizerte by Djellouli (1987) and in Europe by Silva (1955) identified as C. fragile subsp. fragile. However, these data are different from thalli collected in Canada (Hubbard and Garbary 2002, Matheson et al. 2014) and in Korea (Oh et al. 1987). Thallus lengths of Tunisian and European samples (up to $25 \mathrm{~cm}$ ) were smaller than Canadian ones (up to $44 \mathrm{~cm}$ ).

The microscopic characteristics of thalli collected in this study showed that mucrons were long and sharp, with an average of $38.1 \mu \mathrm{m}$ for Marsa samples and 47.2 $\mu \mathrm{m}$ for lagoon of Bizerte samples (Table 2). These measures are similar to mean length of mucrons of $C$. fragile subsp. fragile collected in Europe, but different from measures of mucrons of Canadian C. fragile subsp. fragile. Indicative features such as size and shape of mucron had been used in previous studies to distinguish subspecies of Codium fragile (Trowbridge 1998, Hubbard and Garbary 2002, Matheson et al. 2014). However, since there is a high variability in the mucron shape and dimension, as underlined by Verbruggen et al. (2007), and for unambiguously identification, molecular analysis can be required.

Concerning the position and length of gametangia, there were no significant differences between the present study and previous ones for different $C$. fragile subsp. fragile origins, except for native Korean samples. In fact, Korean samples are distinct from other ones considering length of thallus, utricules, and gametangia (Table 2). Differences between native alga and introduced ones in Canada, Europe, or Tunisia might be due to an ecological adaptation.

\section{Distribution of Codium fragile spp. fragile}

Thalli of C. fragile subsp. fragile were collected in Marsa attached to small rocks. This specie was the most common macroalga associated with the green alga Halimeda tuna and various red and brown algae. In the lagoon of Bizerte $C$. fragile subsp. fragile was common with a native red alga Gracilaria sp. (personal observation).

This north Pacific green alga is an established marine alien species in the Mediterranean (Zenetos et al. 2012). It is identified as one of the Europe's top 10 invasive species (McLaughlan et al. 2014). The oldest European collection dates from 1845 in Ireland (Provan et al. 2008) and it has since spread throughout European Atlantic and Mediterranean coasts. It was discovered on the Netherlands coast in North Sea in 1900 (Silva 1955). It was introduced in the Western Mediterranean across Gibraltar in 1940 (Ver-

Table 3. History of the Codium fragile spread along the Mediterranean North African coastline (Morocco, Algeria, Tunisia, and Libya)

\begin{tabular}{lllcll}
\hline \multirow{2}{*}{ Country } & \multicolumn{1}{c}{ Location } & $\begin{array}{c}\text { Collecting } \\
\text { date }\end{array}$ & $\begin{array}{c}\text { Depth } \\
(\mathbf{m})\end{array}$ & $\begin{array}{c}\text { Identified } \\
\text { as }\end{array}$ & Reference \\
\hline \multirow{2}{*}{ Morocco } & El Jebha & 2000 & - & CF & Riadi et al. (2000) \\
& Mellila & 1994 & - & CF & Benhissoune et al. (2001) \\
\multirow{2}{*}{ Tlgeria } & El-Kala National Park & 2004 & $1-60$ & CFT & Belbacha et al. (2007) \\
& Habibas Islands & 2005 & $1-13$ & CF & Sartoretto et al. (2008) \\
& Lagoon of Bizerte & 1985 & 1 & CF & Djellouli (1987) \\
& Gulf of Tunis & 2000 & $32-51$ & CF & Jarboui et al. (2005) \\
& Ariana (Raoued, Gammarth); Ben Arous & 2005 & - & CF & El Ati-Hellal et al. (2005) \\
& (Rades, Ezzahra, Hammam lif, Hammam & & & & \\
& chatt) & $2005-2006$ & 10 & CF & Zerzeri et al. (2010) \\
& Bizerte (Cap Zbib, Rafraf) & 2007 & - & CF & Gargouri-Ben Ayed et al. (2007) \\
& Sfax (Tidal flat of Nakta) & $2007-2009$ & 1.5 & CF & Shili et al. (2010) \\
& Bizerte, Gammart, Korbous & 2010 & $0-5$ & CFF & Sghaier et al. (2016) \\
& Chott-Mariem & $2010-2011$ & - & CFT & Shili et al. (2014) \\
& Lagoon of Tunis & 2013 & - & CF & Hattour and Ben Mustapha (2013) \\
& Gulf of Gabes & 1984 & - & CFF & Nizamuddin (1991) \\
\hline
\end{tabular}

$\mathrm{CF}$, Codium fragile; CFT, Codium fragile subsp. tomentosoides; CFF, Codium fragile subsp. fragile. 


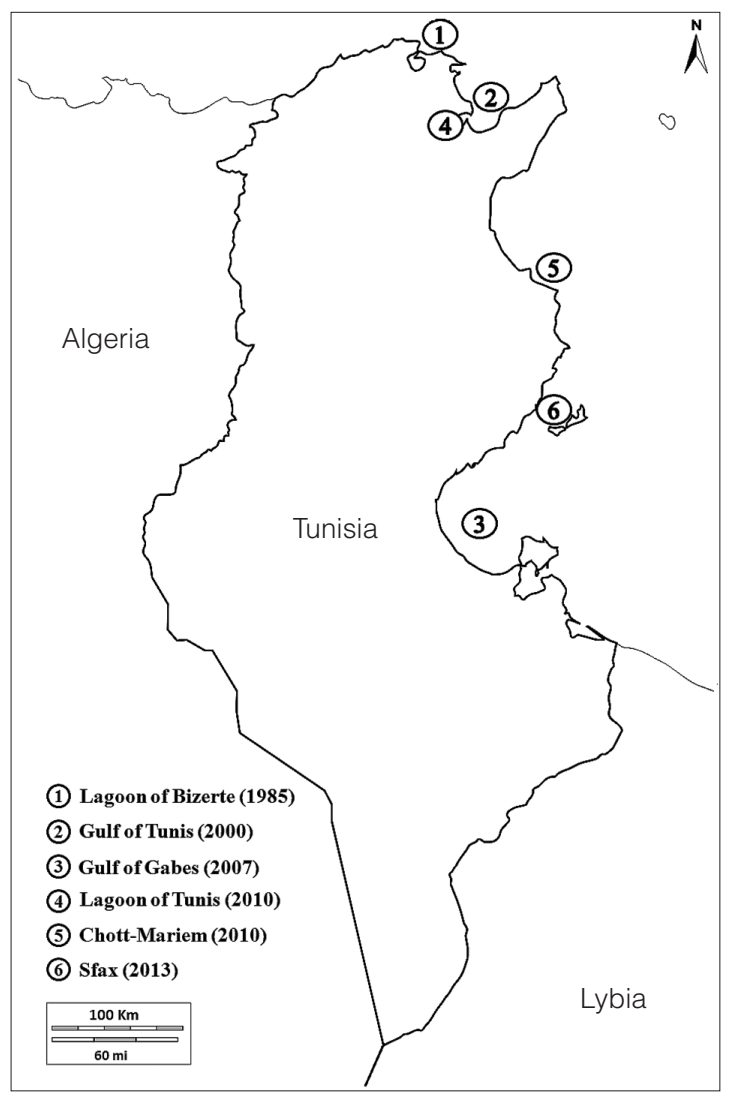

Fig. 2. Historical records of Codium fragile along the Tunisian coasts.

laque 1994). In 1946, it was common in Banyuls (French coast) then it reached Sicily (Battiato et al. 1980) and Tunisia in Bizerte (Djellouli 1987). In the Eastern basin, it has only been reported in the Western region of Libyan coasts (Nizamuddin 1991) (Table 3).

In Tunisia, C. fragile was detected for the first time in the lagoon of Bizerte (Djellouli 1987), a semi-enclosed area that communicates with the Mediterranean Sea through Bizerte channel and with Ichkeul Lake through Oued Tinja. The absence of signalization of $C$. fragile in Tunisian coasts by Menez and Mathieson (1981) and Ben Maiz et al. (1987) let us think that the introduction of C. fragile started in the lagoon and might be associated with mussels and oysters importations from Europe for shellfish farming. However, the establishment of $C$. fragile subsp. fragile in Marsa suggests that the anthropogenic vectors may have contributed to $C$. fragile subsp. fragile transfer later within the Bay of Tunis due to the proximity of La Goulette and Sidi Bou Said harbors and the heavy boat traffic. C. fragile subsp. fragile has been signaled in 2000 in the gulf of Tunis through trawl sampling at 7 to
$8 \mathrm{~m}$ depth (Jarboui et al. 2005). The establishment of $C$. fragile subsp. fragile in the Gulf of Gabes was confirmed in 2013 (Hattour and Ben Mustapha 2013) through an inventory of marine vegetation on the Southern coast (Fig. 2). The data confirm the spread of this invasive species all over Tunisian coasts (Table 3), and show the importance to survey $C$. fragile subsp. fragile expansion mode and its ecological impact.

The invasive green alga $C$. fragile subsp. fragile possesses diverse modes of natural dispersal. In addition to swarmer cells, it can propagate through the release of vegetative buds, thallus fragments, and entire thalli (Watanabe et al. 2009). Male and female gametangia are produced on the utricles, and sexual reproduction is performed through zygotes resulting from the gamete fusion. C. fragile subsp. fragile colonizes intertidal and shallow sub-tidal habitats in temperate seas worldwide (Trowbridge 1998). Moreover, C. fragile subsp. fragile can tolerate a large range of environmental conditions including temperatures from -2 to $33^{\circ} \mathrm{C}$, low light requirements, salinities from 12 to 40 and relatively short periods ( $<6 \mathrm{~h}$ ) of desiccation and exposure to freshwater (Trowbridge 1998, Mathieson et al. 2003). This can explain the dispersal of $C$. fragile subsp. fragile in Tunisia.

\section{Ecological impact}

Invasive non-native species have complex multilevel impacts on their introduced ecosystems. Different studies considered Codium fragile as a nuisance. In fact, in addition to the high biomass; it is responsible of fouling boats and has disadvantageous impact on aquaculture (Trowbridge 1998). Chapman (1999) reported the damaging effects of $C$. fragile in kelp communities on the Atlantic coasts. Scheibling and Anthony (2001) confirmed negative impacts on the sea urchin Strongylocentrotus droebachiensis. The nuisance aspect of C. fragile subsp. fragile is associated with its ability to attach to living shellfish and uproot rhizomes of Zostera marina, so that it has been given different common names such as 'eelgrass thief' or 'oyster thief' (Garbary et al. 2004).

Other studies, in opposition, describe positive effects to $C$. fragile subsp. fragile invasion. In fact, Bulleri et al. (2006) reported that the number of mussel recruits was significantly larger within clumps of $C$. fragile primordia (first stage) than on bare surfaces. Drouin et al. (2011), also, demonstrated an increase in density and diversity of faunal assemblages within eelgrass beds invaded by $C$. fragile.

There is a big gap of information concerning the eco- 
logical effects of $C$. fragile on Tunisian coasts. In Mediterranean Sea, this exotic species is considered to be well established (Verlaque et al. 2015) but the potential negative impacts have never been studied. However, the arrival of other alien macrophytes has brought severe changes in the marine communities in other parts of the Mediterranean Sea (Boudouresque and Verlaque 2002). Thus, it is always important to survey the evolution of alien species. Further sampling and research on biology and ecology of C. fragile subsp. fragile would be helpful to know its real impact on the Tunisian environment.

\section{CONCLUSION}

This study allowed gathering all reports about Codium fragile distribution on Tunisian coasts. It gives a status of the situation of Codium fragile subsp. fragile in this region of Mediterranean Sea. More studies have to be done on this alien alga on environment and human activities impacts. Continuous and careful supervising of the dispersal of the species by using information campaigns towards shellfish farmers, fishermen, etc. would be useful to early detect any possible nuisance.

\section{REFERENCES}

Battiato, A., Cormacci, M. \& Furnari, G. 1980. Alghe marine della Costa Iblea. Atti III. Convegno Siciliano di Ecologia: La Natura e l'Uomo. Noto, Ispica. Cooperativa Universitaria Libraria Catanese (CULC) Press, Catania, pp. 1-38.

Belbacha, S., Semroud, R., Dupuy de la Grandrive, R. D., Foulquie, M. \& Seridi, H. 2007. Données préliminaires sur la biodiversité phytobenthique du littoral d'El Kala (Est Alegria). In Pergent-Martini, C., El Asmi, S. \& Le Ravallec, C. (Eds.) Proc. 3rd Mediterr. Symp. of Marine Veg., RAC/SPA Publication, Tunis, pp. 236-238.

Benhissoune, S., Boudouresque, C. -F. \& Verlaque, M. 2001. A check-list of marine seaweeds of the Mediterranean and Atlantic coasts of Morocco. I. Chlorophyceae Wille $s$. $l$. Bot. Mar. 44:171-182.

Ben Maiz, N., Boudouresque, C. F. \& Ouahchi, F. 1987. Inventaire des algues et phanérogames marines benthiques de la Tunisie. Giorn. Bot. Ital. 121:259-304.

Boudouresque, C. F. \&Verlaque, M. 2002. Biological pollution in the Mediterranean Sea: invasive versus introduced macrophytes. Mar. Pollut. Bull. 44:32-38.

Bulleri, F., Airoldi, L., Branca, G. M. \& Abbiati, M. 2006. Positive effects of the introduced green alga, Codium fragile ssp. tomentosoides, on recruitment and survival of mussels. Mar. Biol. 148:1213-1220.

Burrows, E. M. 1991. Seaweeds of the British Isles. Vol. 2. Chlorophyta. Natural History Museum Press, London, 238 pp.

Chapman, A. S. 1999. From introduced species to invader: what determines variation in the success of Codium fragile ssp. tomentosoides (Chlorophyta) in the North Atlantic Ocean? Helgol. Meeresunters. 52:277-289.

Djellouli, A. 1987. Sur la présence de Codium fragile (Suringar) Hariot (Codiaceae, Ulvophyceae) en Tunisie. Bull. Soc. Linn. Provence 39:103-105.

Drouin, A., McKindsey, C. W. \& Johnson, L. E. 2011. Higher abundance and diversity in faunal assemblages with the invasion of Codium fragile ssp. fragile in eelgrass meadows. Mar. Ecol. Prog. Ser. 424:105-117.

El Ati-Hellal, M., Hedhili, A., Hellal, F., Boujlel, K., Dachraoui, M., Bousnina, M., Ghorbel, H. \& Ndhif, M. 2005. Lead and cadmium concentrations in seawater and algae of the Tunisian coast. Archs. Inst. Pasteur Tunis 82:75-82.

Gallardo, T., Gómez Garreta, A., Ribera, M. A., Cormaci, M., Furnari, G., Giaccone, G. \& Boudouresque, C. F. 1993. Check-list of Mediterranean seaweeds. II. Chlorophyceae Wille $s$. l. Bot. Mar. 36:399-421.

Garbary, D. J., Fraser, S. J., Hubbard, C. \& Kim, K. Y. 2004. Codium fragile: rhizomatous growth in the Zostera thief of eastern Canada. Helgol. Mar. Res. 58:141-146.

Gargouri-Ben Ayed, Z., Souissi, R., Soussi, M., Abdeljaouad, S. \& Zouari, K. 2007. Sedimentary dynamics and ecological state of Nakta Tidal Flat (littoral), south of Sfax, Gulf of Gabès, Tunisia). Chin. J. Geochem. 26:244-251.

Guiry, M. D. \& Guiry, G. M. 2016. AlgaeBase. World-wide electronic publication, National University of Ireland, Galway. Available from: http://www.algaebase.org. Accessed Feb 16, 2016.

Hattour, A. \& Ben Mustapha, K. 2013. The Gulf of Gabes meadows: mapping and monitoring of Posidonia. INSTM Press, Tunis, 164 pp.

Hubbard, C. B. \& Garbary, D. J. 2002. Morphological variation of Codium fragile (Chlorophyta) in eastern Canada. Bot. Mar. 45:476-485.

Jarboui, O., Zamouri, N., Ben Hadj Hamida, N. \& Missaoui, H. 2005. Etude des rejets du chalutage benthique sur les côtes tunisiennes. Laboratoire des Ressources Marines Vivants, Institut National des Sciences et Technologies, Tunis, 25 pp.

Matheson, K., McKenzie, C. H., Sargent, P. S., Hurley, M. \& Wells, T. 2014. Northward expansion of the invasive green algae Codium fragile spp. fragile (Suringar) Hariot, 1889 into coastal waters of Newfoundland, Canada. 
Bioinvasions Rec. 3:151-158.

Mathieson, A. C., Dawes, C. J., Harris, L. G. \& Hehre, E. J. 2003. Expansion of the Asiatic green alga Codium fragile subsp. tomentosoides in the Gulf of Maine. Rhodora 105:1-53.

McLaughlan, C., Gallardo, B. \& Aldridge, D. C. 2014. How complete is our knowledge of the ecosystem services impacts of Europe's top 10 invasive species? Acta Oecol. 54:119-130.

Menez, E. G. \& Mathieson, A. C. 1981. The marine algae of Tunisia. Smithson. Contrib. Mar. Sci. 10:1-59.

Nizamuddin, M. 1991. The green marine algae of Libya. Elga Publishers, Bern, 230 pp.

Oh, Y. S., Lee, Y. P. \& Lee, I. K. 1987. A taxonomic study on the genus Codium, Chlorophyta, in Cheju Island. Korean J. Phycol. 2:62-72.

Petrocelli, A., Cecere, E. \& Verlaque, M. 2013. Alien marine macrophytes in transitional water systems: new entries and reappearances in a Mediterranean coastal basin. Bioinvasions Rec. 2:177-184.

Provan, J., Booth, D., Todd, N. P., Beatty, G. E. \& Maggs, C. A. 2008. Tracking biological invasions in space and time: elucidating the invasive history of the green alga $\mathrm{Co}$ dium fragile using old DNA. Divers. Distrib. 14:343-354.

Riadi, H., Kazzaz, M. \& Ater, M. 2000. Contribution à la connaissance des algues marine benthiques du Détroit de Gibraltar et de la Méditerranée occidentale marocaine. I. Chlorophyceae et phaeophyceae. Acta Bot. Malacitana 25:5-20.

Sartoretto, S., Harmelin, J. -G., Bachet, F., Bejaoui, N., Lebrun, O. \& Zibrowius, H. 2008. The alien coral Oculina patagonica de Angelis, 1908 (Cnidaria, Scleractinia) in Algeria and Tunisia. Aquat. Invasions 3:173-180.

Scheibling, R. E. \& Anthony, S. X. 2001. Feeding, growth and reproduction of sea urchins (Strongylocentrotus droebachiensis) on single and mixed diets of kelp (Laminaria spp.) and the invasisve alga Codium fragile ssp. tomentosoides. Mar. Biol. 139:139-146.

Sghaier, Y. R., Zakhama-Sraieb, R., Mouelhi, S., Vazquez, M., Valle, C., Ramos-Espla, A. A., Astier, J. M., Verlaque, M. \& Charfi-Cheikhrouha, F. 2016. Review of alien marine macrophytes in Tunisia. Mediterr. Mar. Sci. 17:109-123.

Shili, A., Baccar, L., Ben Maïz, N. \& Boudouresque, C. F. 2014. Dynamics of benthic macrophytes in the southern Tunis lagoon (Tunisia, Mediterranean Sea). In Langar, H., Bouafif, C. \& Ouerghi, A. (Eds.) Proc. 5th Mediterr. Symp. Mar. Veg., RAC/SPA Press, Tunis, pp. 172-177.

Shili, A., Ben Maïz, N., Boudouresque, C. F. \& Verlaque, M. 2010. Données sur la prolifération de la rhodobionte
Asparagopsis taxiformis (Delile) Trevisan de Saint-Leon sur les côtes Nord de Tunisie. In El Asmi, S., Langar, H. \& Belgacem, W. (Eds.) Proc. 4th Mediterr. Symp. Mar. Veg., RAC/SPA Press, Tunis, pp. 223-224.

Silva, P. C. 1955. The dichotomous species of Codium in Britain. J. Mar. Biol. Assoc. U. K. 34:565-577.

Trowbridge, C. D. 1995. Establishment of the green alga Codium fragile ssp. tomentosoides on New Zealand rocky shores: current distribution and invertebrate grazers. J. Ecol. 83:949-965.

Trowbridge, C. D. 1998. Ecology of the green macroalga Codium fragile (Suringar) Hariot 1889: invasive and noninvasive subspecies. Oceanogr. Mar. Biol. 36:1-64.

Trowbridge, C. D. \& Todd, C. D. 2001. Host-plant changes of marine specialist herbivores: ascoglossan sea slugs on the introduced macroalgae. Ecol. Monogr. 71:219-243.

Verbruggen, H., Leliaert, F., Maggs, C. A., Shimada, S., Schils, T., Provan, J., Booth, D., Murphy, S., De Clerck, O., Littler, D. S., Littler, M. M. \& Coppejans, E. 2007. Species boundaries and phylogenetic relationships within the green algal genus Codium (Bryopsidales) based on plastid DNA sequences. Mol. Phylogenet Evol. 44:240-254.

Verlaque, M. 1994. Checklist of introduced plants in the mediterranean-origins and impact on the environment and human activities. Oceanol. Acta 17:1-23.

Verlaque, M., Ruitton, S., Mineur, F. \& Boudouresque, C. F. 2015. CIESM atlas of exotic species in the Mediterranean. Vol. 4. Macrophytes. CIESM Press, Monaco, 364 pp.

Watanabe, S., Metaxas, A. \& Scheibling, R. E. 2009. Dispersal potential of the invasive green alga Codium fragile ssp. fragile. J. Exp. Mar. Biol. Ecol. 381:114-125.

Zenetos, A., Gofas, S., Morri, C., Rosso, A., Violanti, D., García Raso, J. E., Çinar, M. E., Almogi-Labin, A., Ates, A. S., Azzurro, E., Ballesteros, E., Bianchi, C. N., Bilecenoglu, M., Gambi, M. C., Giangrande, A., Gravili, C., Hyams-Kaphzan, O., Karachle, P. K., Katsanevakis, S., Lipej, L., Mastrototaro, F., Mineur, F., Pancucci-Papadopoulou, M. A., Ramos Esplá, A., Salas, C., San Martín, G., Sfriso, A., Streftaris, N. \& Verlaque, M. 2012. Alien species in the Mediterranean Sea by 2012: a contribution to the application of European Union's Marine Strategy Framework Directive (MSFD). Part 2. Introduction trends and pathways Mediterr. Mar. Sci. 13:328-352.

Zerzeri, A., Djellouli, A. S., Mezgui, Y. \& Ben Hassine, O. K. 2010. Contribution à la caractérisation de la macroflore benthique des regions de Bizerte, Cap-Zebib Et Raf-Raf (Tunisie, Méditerranée). Rapp. Comm. Int. Mer Méditerr. 39:706. 